Vol. 2 No. 2 (2019)

\title{
STRATEGI PENGUATAN KOMPETENSI SDM TEKNOLOGI INFORMASI\&KOMUNIKASI (TIK) DALAM MENGOPTIMALKAN PENERAPAN SISTEM PEMERINTAHAN BERBASIS ELEKTRONIK (SPBE)
}

\author{
Ludi Awaludin \\ Dinas Komunikasi, Informatika dan Statistik Kabupaten Bandung Barat \\ ludiawaludin28@gmail.com
}

Doi:

\begin{abstract}
Governance based on the development of information technology and innovation requires human resources who have competence in the application of Electronic Based Government Systems (SPBE), namely the administration of government that utilizes information and communication technology to provide services to SPBE Users. Strategy Improvement of human resource (HR) competence in Information \& Communication Technology (ICT) at the Department of Communication and Information and Statistics of West Bandung Regency is done through e-learning methods on computer network competence, programming competence and Multimedia competence. Implementation through the learning of e-learning methods, especially with the introduction of Electronic-Based Government System (SPBE), obtained an average of 9.09 results, which shows that the introduction of SPBE has succeeded in increasing the competence of HR in Information \& Communication Technology (ICT) at the Office of Communication and Information Technology and Statistics of West Bandung Regency.
\end{abstract}

Keywords: HR Competency, e-learning Method, Electronic-Based Government System (SPBE).

\begin{abstract}
Abstrak
Tata kelola pemerintahan berbasis pengembangan teknologi informasi dan inovasi diperlukan sumber daya manusia yang memiliki kompetensi dalam penerapan Sistem Pemerintahan Berbasis Elektronik (SPBE) yaitu penyelenggaraan pemerintahan yang memanfaatkan teknologi informasi dan komunikasi untuk memberikan layanan kepada Pengguna SPBE. Stategi Peningkatan kompetensi sumber daya manusia (SDM) Teknologi Informasi \& Komunikasi (TIK) pada Dinas Kominfo dan statistik Kabupaten Bandung Barat dilakukan melalui metode e-learning pada kompetensi jaringan komputer, kompetensi pemograman dan kompetensi Multimedia. Implementasi melalui pembelajaran metode e-learning yang dilakukan, khususnya dengan materi pengenalan sistem Pemerintahan Berbasis Elektronik (SPBE) diperoleh hasil rata-rata 9,09, yang menunjukkan bahwa pengenalan SPBE berhasil meningkatkan kompetensi SDM Teknologi Informasi \& Komunikasi (TIK) di Dinas Kominfo dan Statistik Kabupaten Bandung Barat.
\end{abstract}


Kata Kunci: Kompetensi SDM, Metode e-learning, Sistem Pemerintahan Berbasis Elektronik (SPBE).

\section{Pendahuluan}

Dalam rangka mewujudkan tata kelola pemerintahan yang baik berbasis pengembangan teknologi informasi dan inovasi diperlukan sumber daya manusia sebagai aset yang paling penting dan berharga serta merupakan faktor yang sangat sentral dalam organisasi. Apapun bentuk dan tujuannya, organisasi dibuat berdasarkan berbagai visi untuk kepentingan manusia yang dalam pelaksanaannya dikelola dan diurus oleh manusia. Dengan demikian manusia merupakan faktor yang sangat strategis dalam semua kegiatan organisasi.

Revolusi teknologi informasi dan komunikasi (TIK) memberikan peluang bagi pemerintah untuk melakukan inovasi dalam rangka peningkatan SDM melalui penerapan Sistem Pemerintahan Berbasis Elektronik (SPBE) yaitu penyelenggaraan pemerintahan yang memanfaatkan teknologi informasi dan komunikasi untuk memberikan layanan kepada Pengguna SPBE.

Dalam pelaksanaannya layanan Sistem Pemerintahan Berbasis Elektronik (SPBE) di Kabupaten Bandung Barat masih menghadapi berbagai permasalahan terutama dalam tatakelola manajemen SDM SPBE dimana adanya keterbatasan jumlah pegawai ASN yang memiliki kompetensi teknis teknologi informasi dan komunikasi (TIK) sehingga optimalisasi pegawai non struktural khususnya pada Dinas Kominfo dan Statistik diperlukan dalam mendukung penerapan SPBE. Begitupun dengan Perkembangan teknologi informasi dan komunikasi (TIK) yang begitu cepat dan dinamis menuntut perluasan dan pendalaman kompetensi teknis yang memadai dalam mendukung penerapan SPBE di Kabupaten Bandung Barat. Untuk memperkuat kompetensi SDM pada Dinas Kominfo dan statistik dalam rangka mendukung penerapan SPBE di Kabupaten Bandung Barat diperlukan Strategi Penguatan Kompetensi SDM Teknologi Informasi \& Komunikasi (TIK) yang diharapkan dapat menjadi salah satu solusi untuk mengoptimalkan Penerapan Sistem Pemerintahan Berbasis Elektronik (SPBE) di Kabupaten Bandung Barat.

Dinas Komunikasi, Informatika dan Statistik Kabupaten Bandung Barat merupakan Perangkat Daerah tipe C yang menyelenggarakan urusan pemerintahan bidang Komunikasi, Informatika, Statistik dan Persandian yang dibentuk berdasarkan Peraturan Daerah Nomor 9 Tahun 2016 tentang Pembentukan dan Susunan Perangkat Daerah Kabupaten Bandung Barat.

Berdasarkan Peraturan Bupati Kabupaten Bandung Barat Nomor 62 Tahun 2016 tentang Kedudukan, Susunan Organisasi, Tugas dan Fungsi serta Tata Kerja Dinas Komunikasi Informatika dan Statistik, disebutkan bahwa Dinas Komunikasi Informatika dan Statistik Kabupaten Bandung Barat mempunyai tugas pokok membantu Bupati melaksanakan urusan Pemerintahan Daerah bidang Komunikasi, Informatika, Statistik dan Persandian yang menjadi kewenangan Daerah dan tugas pembantuan yang diberikan kepada daerah. 
Vol. 2 No. 2 (2019)

Dalam rangka membantu Bupati melaksanakan urusan pemerintahan bidang komunikasi dan informatika, bidang statistik, dan bidang persandian yang menjadi kewenangan daerah dan tugas pembantuan yang ditugaskan kepada daerah, maka strategi perumusan kebijakan organisasi pada bidang komunikasi dan informatika, bidang statistik dan bidang persandian diarahkan pada terwujudnya visi - misi Bupati dan Wakil Bupati Bandung barat Tahun 20182023.

Berdasarkan hasil Forum Grup Discussion (FGD) yang menggunakan metode Root Cause Analysis (RCA), adanya faktor kausal dan alasan apa yang benar-benar menjadi dasar kemunculan masalah dalam penerapan Sistem Pemerintahan Berbasis Elektronik, yaitu :

1. Pemahaman pegawai terhadap SPBE masih rendah

2. Support kinerja dalam penerapan SPBE kurang maksimal

3. Organisasi tidak memiliki staf PNS, mayoritas tenaga non PNS dengan beragam latar belakang pendidikan

4. Keterbatasan kompetensi terutama bidang teknologi informasi dan komunikasi (TIK) dalam menatakelola manajemen SPBE

\section{Identifikasi masalah}

1. Bagaimana pemahaman sumber daya manusia (SDM) bidang TIK Dinas Kominfo dan Statistik dalam penerapan Sistem Pemerintah Berbasis Elektronik (SPBE)

2. Bagaimana Strategi peningkatan kompetensi sumber daya manusia (SDM) bidang TIK Dinas Kominfo dan Statistik dalam rangka optimalisasi penerapan SPBE.

\section{Tinjauan Pustaka}

\section{Manajemen Sumber Daya Manusia (SDM)}

Manajemen sumber daya manusia (human resouces management) adalah pendayagunaan, pengembangan, penilaian, pemberian balas jasa, dan pengelolaan individu anggota organisasi atau kelompok pekerja (Henry Simamora, 2001 :3). Manajemen SDM pada organisasi pemerintahan memegang peran penting dan strategis dalam tugas dan fungsinya terhadap pelayanan masyarakat.

\section{Kompetensi Sumber Daya Manusia (SDM)}

TIK di Indonesia sebagai bidang yang relatif belum terlalu lama dikenal pastinya perlu mengembangkan kualitas SDM nya. Untuk itu perlu disusun Strategi Pengembangan SDM TIK. Penyusunan Strategi Pengembangan SDM TIK bertumpu pada keselarasan dan kolaborasi antara pemerintah, akademik, industri, dan masyarakat dalam pengembangan SDM TIK termasuk pemberdayaan TIK sehingga pembangunan TIK dapat dilakukan secara komprehensif dan tepat sasaran. Jika pembangunan TIK oleh pemerintah dilakukan secara otonomi sampai unit organisasi terendah tanpa keselarasan dan kolaborasi dengan akademik dan industri, hal ini dapat menyebabkan tidak terintegrasinya kompetensi SDM TIK secara menyeluruh. Strategi ini memiliki 5 sasaran yang mana setiap sasaran memiliki beberapa indikator untuk pencapaiannya yaitu:

1. Meningkatkan kapasitas SDM TIK dari segi keahlian dan pendidikan

a. Rata-rata tingkat pendidikan SDM TIK meningkat. 
Vol. 2 No. 2 (2019)

b. Sertifikasi dan kompetensi SDM TIK meningkat.

c. Mengembangkan pendidikan dan pelatihan berbasis SKKNI di pusat-pusat diklat dan LSP.

d. Meningkatkan penyediaan beasiswa di bidang TIK.

e. Menggunakan TIK dengan lebih produktif.

2. Membentuk SDM TIK yang gesit, fleksibel, dan berpandangan ke depan

a. Mengembangkan kerjasama dengan Centre of Excellence di bidang TIK baik di dalam maupun di luar negeri.

b. Mengembangkan pemberdayaan Technology Centre sebagai pusat inkubator bisnis TIK.

3. Meningkatkan literasi TIK pada masyarakat umum

a. Mengintegrasikan TIK ke kurikulum di sekolah.

b. Memfasilitasi pelatihan TIK dasar untuk masyarakat.

c. Meningkatkan pelatihan TIK untuk para pengajar di sekolah.

d. Meningkatkan akses masyarakat ke fasilitas TIK, seperti komputer dan internet.

e. Memanfaatkan TIK dengan lebih bijak.

4. Mengembangkan kemampuan teknis yang beragam pada komunitas TIK di industri, pemerintah, dan akademisi

a. Membentuk dan mengembangkan database expert bidang keahlian dari SDM TIK yang beragam di Indonesia.

b. Membentuk dan mengembangkan cluster bidang keahlian TIK yang beragam di Indonesia. c. Memfasilitasi dan mendukung pengembangan dan pemberdayaan cluster bidang keahlian TIK yang beragam di Indonesia.

5. Mengembangkan pemberdayaan SDM TIK dalam inovasi, pengembangan, dan penyediaan produk dan jasa terkini.

a. Memfasilitasi pengelolaan (termasuk men-trigger) intellectual property, termasuk paten, copyright, trademark, dan desain industri di bidang TIK.

b. Memfasilitasi dan mendukung (termasuk men-trigger) kreativitas dalam berinovasi dan mengembangkan produk dan jasa di bidang TIK.

c. Aktif dalam menyelenggarakan ajang lomba dan pertunjukan (exhibition) inovasi dan riset di bidang TIK.

Kementerian Kominfo mengeluarkan Peraturan Menteri Komunikasi dan Informatika Republik Indonesia Nomor 24 Tahun 2015 tentang Pemberlakuan Standar Kompetensi Kerja Nasional Indonesia Bidang Komunikasi dan Informatika. Didalam pasal 5 terdapat aturan sebagai berikut :

a. SKKNI Bidang Kominfo harus diberlakukan terhadap tenaga kerja industri, baik tenaga kerja Indonesia maupun Tenaga Kerja Asing, yang keahlian atau keterampilannya di bidang komunikasi dan informatika.

b. SKKNI Bidang Kominfo berlaku secara nasional.

c. Dalam hal SKKNI Bidang Kominfo tidak dilaksanakan sesuai ketentuan, maka 
dikenakan sanksi sesuai ketentuan peraturan perundangundangan.

Didalam Pasal 6 ayat 2 terdapat kewajiban pemberlakuan SKKNI bagi tenaga kerja, yang berbunyi : Pemberlakuan SKKNI Bidang Kominfo sebagaimana dimaksud pada ayat (1) dilakukan secara bertahap, dengan menggunakan perhitungan sebagaimana berikut, untuk:

a. tahun kesatu pemberlakuan wajib, $20 \%$ (dua puluh perseratus) dari total tenaga kerja yang menjadi obyek pemberlakuan SKKNI Bidang Kominfo yang telah ditetapkan;

b. tahun kedua pemberlakuan wajib, $40 \%$ (empat puluh perseratus) dari total tenaga kerja yang menjadi obyek pemberlakuan SKKNI Bidang Kominfo yang telah ditetapkan;

c. tahun ketiga pemberlakuan wajib, $60 \%$ (enam puluh perseratus) dari total tenaga kerja yang menjadi obyek pemberlakuan SKKNI Bidang Kominfo yang telah ditetapkan;

d. tahun keempat pemberlakuan wajib, $80 \%$ (delapan puluh perseratus) dari total tenaga kerja yang menjadi obyek pemberlakuan SKKNI Bidang Kominfo yang telah ditetapkan;

e. tahun kelima pemberlakuan wajib, $\quad 100 \% \quad$ (seratus perseratus) dari total tenaga kerja yang menjadi obyek pemberlakuan SKKNI Bidang Kominfo yang telah ditetapkan.

Peraturan menteri ini merujuk pada ketentuan Pasal 4 ayat (2) huruf c Peraturan Menteri Tenaga Kerja dan
Transmigrasi Nomor 8 Tahun 2012 tentang Tata Cara Penetapan Standar Kompetensi Kerja Nasional Indonesia. Saat ini masih belum tersedia aturan pelaksanan UU Nomor 7 Tahun 2014 tentang Perdagangan terutama mengenai kewajiban dan pengenaan sanksi terhadap penyedia jasa yang tidak memiliki tenaga teknis yang kompeten.

\section{Sistem Pemerintahan Berbasis Elektronik}

Sistem Pemerintahan Berbasis Elektronik merupakan upaya berkesinambungan dalam pembangunan aparatur negara untuk mewujudkan bangsa yang berdaya saing. Pada akhir tahun 2025 diharapkan pemerintah sudah berhasil mencapai keterpaduan SPBE baik di dalam dan antar Instansi Pusat dan Pemerintah Daerah, dan keterhubungan SPBE antara Instansi Pusat dan Pemerintah Daerah. Dengan SPBE yang terpadu, diharapkan akan menciptakan proses bisnis pemerintahan yang terintegrasi antara Instansi Pusat dan Pemerintah Daerah sehingga akan membentuk satu kesatuan pemerintahan yang utuh dan menyeluruh serta menghasilkan birokrasi pemerintahan dan pelayanan publik yang berkinerja tinggi.

Untuk mencapai hal tersebut, setiap Instansi Pusat dan Pemerintah Daerah perlu melakukan transformasi paradigma dan proses dalam konteks penyelenggaraan pemerintahan, pelayanan publik berbasis elektronik, dukungan TIK dan SDM.

Perkembangan TIK yang sangat pesat memberi peluang inovasi TIK dalam penyelenggaraan pemerintahan. Diharapkan pemanfaatan TIK yang efektif dan efisien dapat dicapai melalui integrasi infrastruktur, sistem aplikasi, 
keamanan informasi, dan layanan TIK. Tren TIK di masa depan dapat diadopsi secara selektif yang disesuaikan dengan kondisi lingkungan internal dan eksternal.

SDM di bidang TIK memegang peranan paling penting untuk mewujudkan SPBE yang terpadu dan berkesinambungan. Diharapkan pegawai ASN di instansi pemerintah memiliki kepemimpinan dan kompetensi teknis TIK memiliki tingkat literasi SPBE yang memadai sehingga layanan SPBE dapat diselenggarakan dan dimanfaatkan dengan optimal. Kepemimpinan SPBE diharapkan memiliki karakteristik sebagai berikut:

a. Kolaboratif yaitu kepemimpinan yang meninggalkan ego sektoral dan mendorong penggunaan sumber daya secara bersama di dalam instansi pemerintah dan antar instansi pemerintah untuk mencapai tujuan bersama; dan

b. Inovatif yaitu kepemimpinan yang mampu mendorong pelaksanaan spbe berorientasi pada efisiensi, efektivitas, dan manfaat yang bernilai tinggi.

Kompetensi teknis SPBE diharapkan dimiliki oleh pegawai ASN yang terlibat dalam pelaksanaan SPBE antara lain dalam bidang perencanaan SPBE, rekayasa proses bisnis pemerintahan, pengelolaan TIK yang terintegrasi, aman, dan andal, dan pengelolaan layanan yang inovatif, adaptif dan responsif. Budaya SDM dikembangkan untuk mewujudkan SDM aparatur yang mampu berfikir kreatif, sistemik, berwawasan global, memiliki etos kerja yang tinggi, mampu mengelola perubahan lingkungan strategis, dan memberikan pelayanan proaktif yang sesuai dengan kebutuhan masyarakat.
Dalam upaya menerapkan SPBE di Kabupaten Bandung Barat, secara suprastruktur sebetulnya sudah sangat mendukung, Organisasi telah memiliki regulasi terkait SPBE, yaitu RPJMD, Renstra Dinas, Perda No. 4 Tahun 2019 tentang Penyelenggaraan Komunikasi, Informatika dan Statistik, Perbup No. 9 Tahun 2017 tentang Pengembangan Pemerintahan Berbasis Elektronik Di Lingkungan Pemerintah Daerah dan SK Bupati tentang Nomor : 188.45/Kep. 286 - Diskominfotik/2017 Tentang Pembentukan Komite Teknologi Informasi dan Komunikasi di Lingkungan Pemerintah Kabupaten Bandung Barat. Berdasarkan hasil evaluasi SPBE saat ini, Kabupaten Bandung Barat mendapat predikat baik dengan nilai 2,61.

Penyelenggaraan Sistem Pemerintahan Berbasis Elektronik diatur dalam Peraturan Presiden Nomor 95 Tahun 2018 yang mencakup ruang lingkup pengaturan berikut :

1) Tata Kelola SPBE;

2) Manajemen SPBE;

3) Audit Teknologi Informasi dan Komunikasi;

4) Penyelenggara SPBE;

5) Percepatan SPBE; dan

6) Pemantauan dan evaluasi SPBE.

Dinas Komunikasi, Informatika dan Statistik Kabupaten Bandung Barat yang menyelenggarakan urusan pemerintahan bidang Komunikasi, Informatika, Statistik dan Persandian melaksanakan pengelolaan SPBE sebagai upaya untuk mengembangkan penyelenggaraan kepemerintahan yang memanfaatkan TIK dalam rangka meningkatkan kualitas layanan publik secara efektif dan efisien.

Sebagaimana Peraturan Presiden Nomor 95 Tahun 2018 tentang Sistem 
Pemerintahan Berbasis Elektronik (SPBE) disebutkan bahwa tata Kelola SPBE dilaksanakan sebagai kerangka kerja yang memastikan terlaksananya pengaturan, pengarahan, dan pengendalian dalam penerapan SPBE secara terpadu.

Lebih dari pada itu, dalam Perpres tersebut diatur didalamnya mencakup juga tentang pengaturan manajemen sumber daya manusia. Manajemen sumber daya manusia dalam penerapan SPBE dilakukan dalam rangka memastikan ketersediaan dan kompetensi.

\section{Strategi Pemberdayaan Organisasi Pembelajaran}

Penguatan kompetensi SDM bidang TIK dapat dilakukan dengan cara membentuk organisasi pembelajaran di lingkungan internal Dinas Komunikasi, Informatika dan Statistik.

Dalam era globalisasi saat ini, organisasi harus dapat mengubah secara terus menerus dan kreatif, mencari ide dan kesempatan yang baru dengan cara melakukan pembelajaran dalam institusinya, sehingga menjadi organisasi pembelajaran (learning organization). Konsep organisasi pembelajaran (learning organization) dibuat populer pada awal tahun 1990an oleh Peter Senge dalam bukunya The fifth discipline. Konsep ini menginformasikan bahwa suatu organisasi dapat bertahan dan menjadi sukses, apabila organisasi tersebut menjadi learning organization (Senge, 1990:14). Learning organization merupakan suatu organisasi yang setiap anggotanya secara terus menerus meningkatkan kemampuannya untuk menciptakan hasil yang benar-benar diinginkan, pola pikir baru yang ekspansif ditumbuhkan, aspirasi bersama dikembangkan secara bebas, dan anggota-anggotanya secara terus menerus belajar bagaimana organisasi itu mengembangkan belajar bersama-sama (Senge, 1990:3).

Marquardt mendefinisikan learning organization secara sistematis yaitu suatu organisasi yang belajar secara kuat dan kolektif dan mentransformasikan secara terus menerus organisasinya untuk mengoleksi, mengelola, dan menggunakan pengetahuan secara lebih baik untuk kesuksesan institusinya. Learning organization memberdayakan orang di dalam dan di luar organisasinya untuk belajar seperti mereka bekerja (1996: 234).

Menurut Marquardt (2002:23-24) bahwa dalam membangun learning organization tidak mungkin dapat dilakukan tanpa memahami dan mengembangkan lima bagian dari model sistem learning organization yang saling berhubungan. Kelima bagian dari model sistem learning organization yaitu: pembelajaran (learning), organisasi (organization), orang (people), pengetahuan (knowledge), dan teknologi (technology). Kelima bagian dari sistem learning organization itu perlu menopang secara aktif, sehingga mengembangkan terus pembelajaran organisasional dan mencapai keberhasilan organisasi selanjutnya. Adapun model sistem learning organization dapat ditunjukkan pada Gambar 1. berikut ini. 


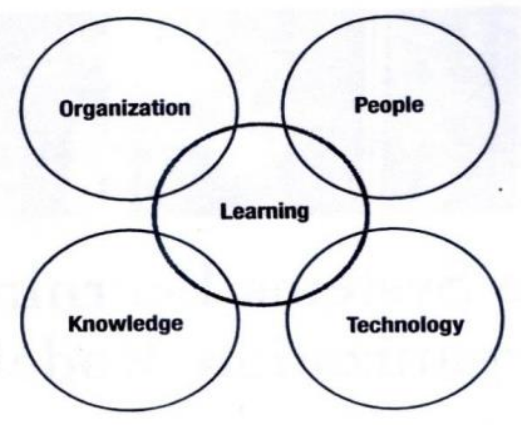

Gambar 3.1 Model Sistem Learn ing

Organization

Gambar tersebut menunjukkan bahwa empat bagian dari model sistem learning organization yaitu: organisasi (organization), orang (people), pengetahuan (knowledge), dan teknologi (technology) diperlukan untuk meningkatkan dan memperluas bidang pembelajaran (learning), sehingga dapat menyerap empat bagian tersebut. Semua bagian dari model sistem learning organization itu merupakan aspek-aspek yang sangat diperlukan dalam membangun dan memelihara learning organization. Kelima bagian itu saling berhubungan dan saling melengkapi secara dinamis satu dengan yang lain. Jika ada satu bagian yang lemah, maka bagian lainnya dapat disesuaikan dan dikompromikan secara signifikan.

Dalam bagian pembelajaran ini mengacu pada tiga aspek, yaitu: (1) ketrampilan pembelajaran, (2) tingkat pembelajaran, dan (3) jenis pembelajaran. Ketiga aspek ini sangat penting bagi learning organization sebagaimana ditunjukkan pada Gambar 2 berikut ini.

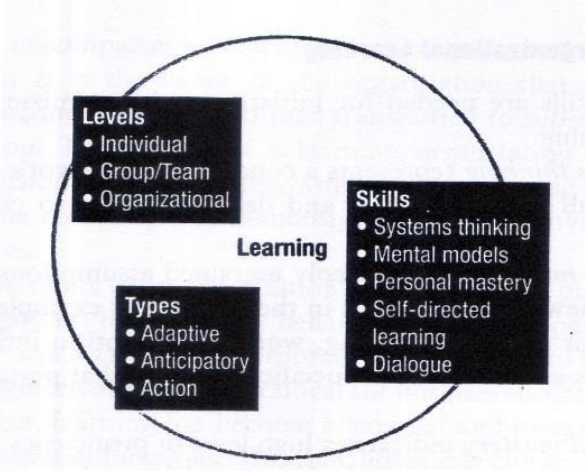

Gambar 3.2

Aspek Pembelajaran dalam Learning

Organization

\section{Metodologi}

1. Metode Penelitian

Metode yang digunakan adalah metode Eksperimen, yaitu suatu penelitian yang berusaha mencari pengaruh variabel tertentu terhadap variabel yang lain dalam kondisi yang terkontrol secara ketat. Variabel independennya dimanipulasi oleh peneliti

\section{Teknik Pengumpulan data \\ Pengumpulan Data dilakukan} melalui :

a. Observasi Partisipan

b. Wawancara dengan para stakeholder terkait, yaitu

Stakeholder Internal

1) Sekretaris Dinas

2) Kepala Bidang Aplikasi Informatika Pemerintahan

3) Kepala Bidang Informasi dan Komunikasi Publik

4) Kepala Sub Bagian Kepegawaian dan Umum

5) Kepala Seksi Informasi dan Komunikasi Publik

6) Kepala Seksi Infrastruktur dan Teknologi 
7) Kepala Seksi Manajemen Data dan Pengembangan Aplikasi

8) Kepala Seksi Layanan EGovernment

\section{Stakeholder Eksternal}

1) Sekretaris Daerah

2) Kepala Badan Perencanaan Pembangunan, Penelitian dan Pengembangan Daerah

3) Kepala Badan Kepegawaian dan Pengembangan SDM

4) Balai Pelatihan dan Pengembangan TIK Cikarang Kemenkominfo RI

5) Balai Pengembangan Sumber Daya Manusia dan Penelitian Komunikasi dan Informatika (BPSDMP

Kominfo) Bandung

Kemenkominfo RI

6) PT. Telkom Indonesia

7) LKBN ANTARA

c. Focus Group Discussion (FGD)

\section{Populasi dan Sampel}

Penelitian dilakukan dengan menggunakan teknik sensus, yaitu seluruh pegawai pada Dinas Kominfo dan Statistik Kabupaten Bandung Barat sebagai responden, berjumlah 41 orang.

\section{Teknik Analisis data}

Dilakukan melalui tahapan sebagai berikut :

- Melakukan Pre- test

- Melaksanakan KBM melalui metode e-learning

- Melaksanakan Post-test

- Melaksanakan Evaluasi pembelajaran

V. Pembahasan

1. Pemahaman sumber daya manusia (SDM) bidang TIK Dinas Kominfo dan Statistik dalam penerapan Sistem Pemerintah Berbasis Elektronik (SPBE)

Kondisi eksisting penerapan Sistem Pemerintahan Berbasis Elektronik pada Dinas Kominfo dan Statistik Kabupaten Bandung Barat, berdasarkan hasil forum grup discussion yang menggunakan metode Root Cause Analysis (RCA) digambarkan dalam tabel berikut :

\section{Tabel Hasil Forum Grup Discussion dengan Menggunakan Metode RCA}

\begin{tabular}{|c|c|c|c|}
\hline NO. & SEBAB & AT & $\begin{array}{c}\text { ALASAN } \\
\text { YANG MEMPENGARUHI }\end{array}$ \\
\hline 1. & $\begin{array}{l}\text { Dalam upaya mengoptimalkan } \\
\text { pelaksanaan SPBE, masalah } \\
\text { yang dihadapi kinerja } \\
\text { organisasi berkenaan dengan } \\
\text { aspek kelembagaan, SDM, } \\
\text { sarana prasarana pendukung } \\
\text { dan penganggaran. } \\
\text { Gejalanya : } \\
\text { - Kelembagaan dinas masih } \\
\text { bertipe C dengan hanya } \\
\text { memiliki } 2 \text { bidang dan } 6 \\
\text { seksi, sehingga } \\
\text { kapasitasnya terlalu kecil } \\
\text { untuk mengakselerasikan } \\
\text { implementasi SPBE. }\end{array}$ & $\begin{array}{l}\text { Dampaknya sebagai } \\
\text { berikut : } \\
\text { - } \quad \text { Akselerasi organisasi } \\
\text { menjadi lambat. } \\
\text { - } \text { Organisasi tidak akan } \\
\text { mampu } \\
\text { mengantisipasi } \\
\text { perkembangan } \\
\text { dinamika ke depan }\end{array}$ & $\begin{array}{l}\text { Bidang IKP memiliki beban } \\
\text { kerja yang terlalu tinggi } \\
\text { terkait dengan } \\
\text { penyelenggaraan } \\
\text { kewenangan/urusan } \\
\text { pemerintahan } \\
\text { Persandian(keamanan } \\
\text { Informasi), penyelenggaraan } \\
\text { Statistik Sektoral dan Bidang } \\
\text { IKP sendiri, sehingga } \\
\text { akselerasinya lambat. } \\
\text { Dinas hanya memiliki } 13 \\
\text { PNS, 11 merupakan pejabat } \\
\text { structural, 2 orang staf } \\
\text { fungsional (hanya } 2 \text { orang }\end{array}$ \\
\hline
\end{tabular}




\begin{tabular}{|c|c|c|c|}
\hline & $\begin{array}{l}\text { - Organisasi tidak memiliki } \\
\text { staf PNS mayoritas tenaga } \\
\text { PTT yang sedikit memiliki } \\
\text { latar belakang kompetensi } \\
\text { teknologi informasi. } \\
\text { Sarana prasarana } \\
\text { pendukung organisasi } \\
\text { kurang memadai. } \\
\text { Pembiayaan sudah terukur } \\
\text { sesuai RPJMD dan } \\
\text { Renstra, namun nilainya } \\
\text { masih belum sesuai } \\
\text { indikasi kebutuhan. }\end{array}$ & & $\begin{array}{l}\text { yang berbasis kompetensi IT) } \\
\text { dan } 41 \text { Non PNS PTT (hanya } \\
9 \text { orang yang berbasis } \\
\text { kompetensi IT) sehingga } \\
\text { kuantitas \& kualitasnya } \\
\text { belum memadai walaupun } \\
\text { sudah ditunjang } 3 \text { tenaga } \\
\text { programer. } \\
\text { Sarana ruang perkantoran } \\
\text { terlalu kecil dan kurang } \\
\text { nyaman, masih belum } \\
\text { memiliki ruang rapat, ruang } \\
\text { studio/laboratorium, gudang, } \\
\text { ruang server yang memadai, } \\
\text { apalagi ketika harus } \\
\text { menampung perkembangan } \\
\text { aktivitas organisasi ke depan } \\
\text { seperti rencana membuat } \\
\text { command center. } \\
\text { Alokasi penganggaran sudah } \\
\text { tersedia, namun pembiayaaan } \\
\text { untuk peralatan dan } \\
\text { pengembangan infrastruktur } \\
\text { nilai harganya selalu naik } \\
\text { sehingga terkadang untuk } \\
\text { menutupinya mengganggu } \\
\text { kebutuhan opersional dinas. }\end{array}$ \\
\hline 2. & 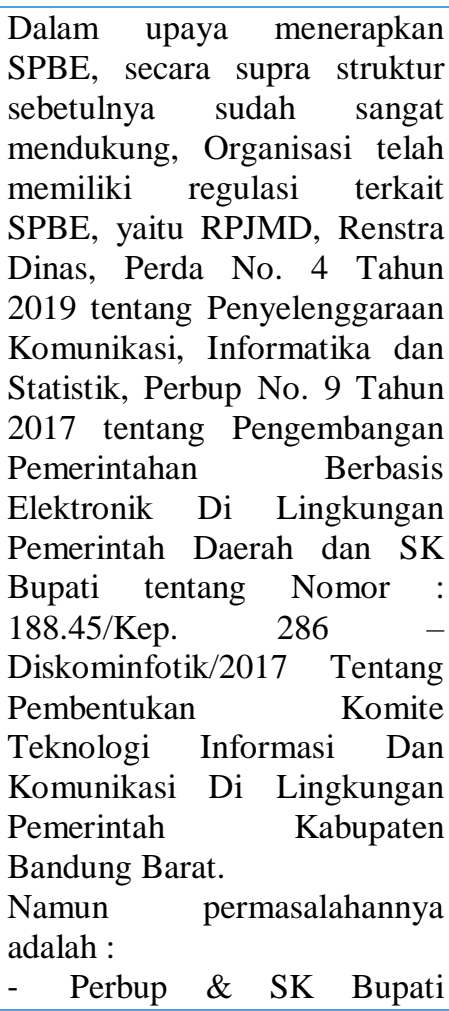 & $\begin{array}{l}\text { Dampaknya sebagai } \\
\text { berikut : } \\
\text { - Manajemen dan tata } \\
\text { kelola SPBE belum } \\
\text { optimal dilaksanakan. } \\
\text { - Sehingga proses } \\
\text { koordinasi menjadi } \\
\text { sulit dilakukan. } \\
\text { Belum mendapat } \\
\text { kepercayaan (trust) } \\
\text { yang besar dari } \\
\text { perangkat daerah lain } \\
\text { sebagai costumer. }\end{array}$ & $\begin{array}{l}\text { Kondisi di atas faktanya sebagai } \\
\text { berikut: } \\
\text { - } \text { Ruang lingkup } \\
\text { penyelenggaraan SPBE yang } \\
\text { meliputi: Tata Kelola SPBE, } \\
\text { Manajemen SPBE, Audit } \\
\text { Teknologi Informasi dan } \\
\text { Komunikasi, penyelenggara } \\
\text { SPBE, percepatan SPBE dan } \\
\text { pemantauan dan evaluasi } \\
\text { SPBE belum dirumuskan dan } \\
\text { dijelaskan dalam Perbup. } \\
\text { SK BUpati Nomor } \\
\text { 188.45/Kep. 286 } \\
\text { Diskominfotik/2017 Tentang } \\
\text { Pembentukan Komite } \\
\text { Teknologi Informasi Dan } \\
\text { Komunikasi Di Lingkungan } \\
\text { Pemerintah Kabupaten } \\
\text { Bandung Barat belum } \\
\text { diselaraskan dengan cakupan } \\
\text { yang tertuang dalam } \\
\text { ketentuan SPBE. ini tidak } \\
\text { Pada Tahun angaran } \\
\text { diakomodir a a a }\end{array}$ \\
\hline
\end{tabular}


Vol. 2 No. 2 (2019)

\begin{tabular}{|c|c|c|c|}
\hline & $\begin{array}{l}\text { tersebut harus direviu } \\
\text { kembali sesuai Perda dan } \\
\text { Pedoman SPBE. } \\
\text { Ketentuan } \\
\text { penyelenggaraan SPBE } \\
\text { belum banyak dipahami } \\
\text { oleh pemangku tugas pada } \\
\text { setiap perangkat daerah, } \\
\text { termasuk pada internal } \\
\text { organisasi Diskominfotik. } \\
\text { Masih banyak perangkat } \\
\text { daerah yang belum } \\
\text { memahami peran dan } \\
\text { kedudukan organisasi } \\
\text { dinas. } \\
\text { Gejalanya : } \\
\text { Terdapat } \\
\text { ketentuan SPBE yang } \\
\text { belum diatur secara jelas } \\
\text { dalam Perbup \& SK } \\
\text { Bupati tersebut. } \\
\text { Sampai saat ini belum } \\
\text { dilakukan diseminasi atau } \\
\text { sosialisasi yang berkenaan } \\
\text { dengan ketentuan SPBE } \\
\text { termasuk Perda No. } 4 \\
\text { Tahun 2019 tentang } \\
\text { Penyelenggaraan } \\
\text { Komunikasi, Informatika } \\
\text { dan Statistik. } \\
\text { Bahkan banyak di internal } \\
\text { organisasi yang belum } \\
\text { memahaminya juga. } \\
\text { Perangkat Daerah banyak } \\
\text { yang belum paham } \\
\text { mengenai tata kelola } \\
\text { infrastruktur IT } \\
\text { pemamfaatan aplikasi atau } \\
\text { system informasi lainnya. }\end{array}$ & & $\begin{array}{l}\text { kegiatan diseminasi atau } \\
\text { sosialisasi terkait dengan } \\
\text { ketentuan SPBE termasuk } \\
\text { Perda No. } 4 \text { Tahun 2019 } \\
\text { tentang Penyelenggaraan } \\
\text { Komunikasi, Informatika dan } \\
\text { Statistik. } \\
\text { Manajemen \& tata kelola } \\
\text { system informasi termasuk } \\
\text { pemanfaatan jaringan } \\
\text { internet belum berjalan } \\
\text { secara sinergis \& sulit } \\
\text { diintegrasikan, contohnya } \\
\text { integrasi proses bisnis } \\
\text { perencanaan } \\
\text { penganggaran-pelaporan - } \\
\text { pengawasan (audit) }\end{array}$ \\
\hline 3. & $\begin{array}{l}\text { Masalah yg dihadapi seksi } \\
\text { Infrastruktur dan teknologi } \\
\text { berkaitan dengan penerapan } \\
\text { SPBE adalah bahwa SPBE } \\
\text { memerlukan Teknologi } \\
\text { Informasi yang memadai, yaitu } \\
\text { : } \\
\text { - Pusat Data (Data Center) } \\
\text { yang terstandar } \\
\text { Jaringan Intra Pemerintah } \\
\text { dan Stakeholder } \\
\text { pendukung lainnya }\end{array}$ & $\begin{array}{l}\text { Dampak yang dirasakan } \\
\text { terhadap kinerja adalah } \\
\text { sebagai berikut : } \\
\text { - Banyaknya } \\
\text { Maintenance dan } \\
\text { Troubleshooting pada } \\
\text { Data Center } \\
\text { Banyaknya } \\
\text { Maintenance dan } \\
\text { Troubleshooting pada } \\
\text { Jaringan } \\
\text { - Perbedaan }\end{array}$ & 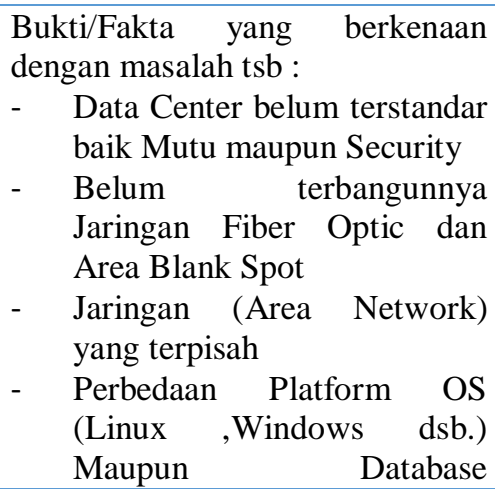 \\
\hline
\end{tabular}




\begin{tabular}{|c|c|c|c|}
\hline & 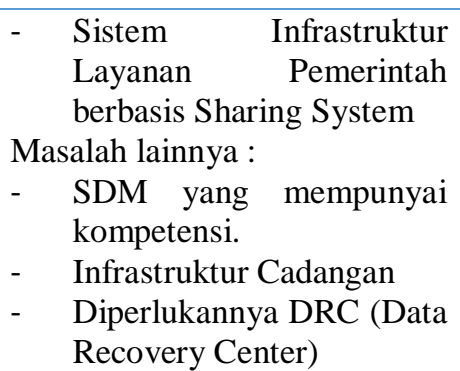 & $\begin{array}{l}\text { Jaringan,Platform dan } \\
\text { Security memerlukan } \\
\text { penyelarasan } \\
\text { Teknologi yang } \\
\text { simultan }\end{array}$ & $\begin{array}{l}\text { (MySQL,Windows Server } \\
\text { dll) } \\
\text { - } \\
\text { Perangkat Security (firewall) } \\
\text { belum terstandar }\end{array}$ \\
\hline 4. & $\begin{array}{l}\text { Masalah yang dirasakan } \\
\text { berkenaan dengan pemahaman } \\
\text { penerapan SPBE oleh } \\
\text { pimpinan dan stakeholder di } \\
\text { Pemerintah Daerah yang } \\
\text { mengakibatkan dukungan } \\
\text { melalui penerapan kebijakan } \\
\text { serta anggaran belum memadai } \\
\text { untuk implementasi SPBE di } \\
\text { Kabupaten Bandung Barat. } \\
\text { Salah satu gejalanya antara } \\
\text { lain penerapan standar ruang } \\
\text { server belum memadai, } \\
\text { Terdapat banyak Perangkat } \\
\text { Daerah yang } \\
\text { membuat/mengembangkan } \\
\text { aplikasi tanpa koordinasi } \\
\text { dengan Diskominfotik, belum } \\
\text { adanya backup dan } \\
\text { contingency plan, pemahaman } \\
\text { pegawai terhadap SPBE masih } \\
\text { rendah. }\end{array}$ & $\begin{array}{l}\text { Dampak yang dirasakan } \\
\text { banyaknya aduan terkait } \\
\text { layanan Diskominfotik } \\
\text { (jaringan dan aplikasi) }\end{array}$ & $\begin{array}{l}\text { Faktanya, terdapat aplikasi yang } \\
\text { tidak terintegrasi dengan server } \\
\text { Diskominfotik, banyaknya } \\
\text { pegawai yang tidak memahami } \\
\text { proses bisnis suatu aplikasi } \\
\text { sehingga menjadi tidak efisien } \\
\text { dan efektif. }\end{array}$ \\
\hline 5. & 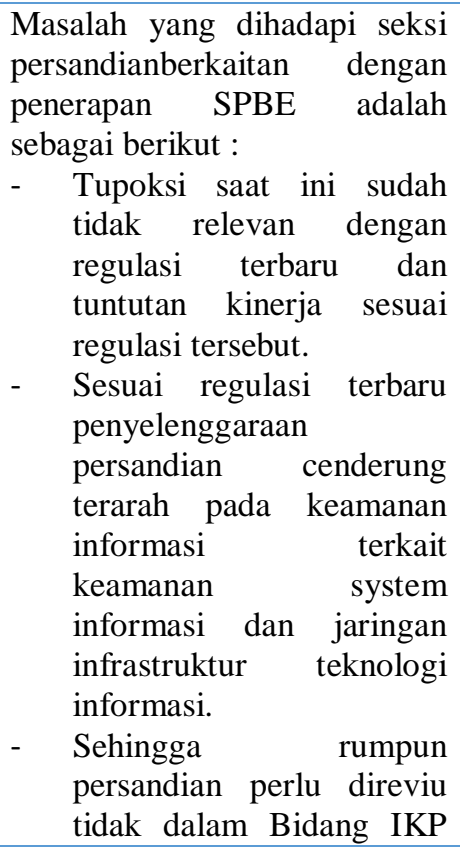 & $\begin{array}{lr}\text { Dampak apa } & \text { yang } \\
\text { dirasakan dengan adanya } & \text { tersebut } \\
\text { masalah } & \text { manajemen } \\
\text { diantaranya } & \text { meamanan informasi yang } \\
\text { kemang } & \text { meliputi penetapan ruang } \\
\text { lingkup, } & \text { penetapan } \\
\text { penanggung } & \text { jawab, } \\
\text { perencanaan, } & \text { dukungan } \\
\text { pengoperasian, } & \text { evaluasi } \\
\text { kinerja, dan } & \text { perbaikan } \\
\text { berkelanjutan } & \text { terhadap } \\
\text { keamanan } & \text { informasi } \\
\text { dalam SPBE belum terasa } \\
\text { dilaksanakan }\end{array}$ & $\begin{array}{l}\text { Bukti atau fakta berkenaan } \\
\text { dengan masalah tersebut } \\
\text { diantaranya pelaksanaan program } \\
\text { dan kegiatan masih sangat } \\
\text { terbatas yang dapat dilakukan } \\
\text { dalam penyelenggaraan seksi } \\
\text { persandian (keamanan informasi) }\end{array}$ \\
\hline
\end{tabular}




\begin{tabular}{|c|c|c|c|}
\hline & 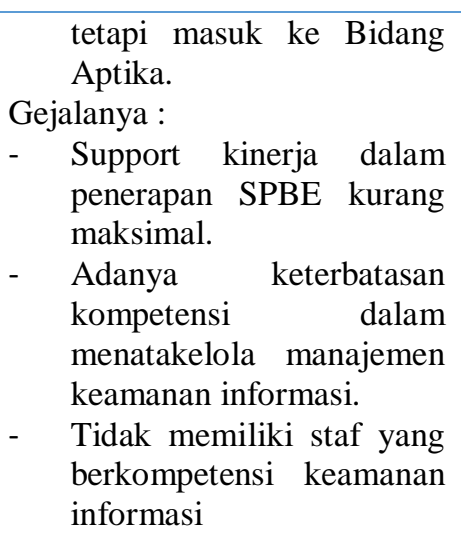 & & \\
\hline 6. & $\begin{array}{lr}\text { Masalah yang } & \text { dihadapi } \\
\text { berkaitan dengan penerapan } & \text { peneses } \\
\text { SPBE adalah manajemen data } \\
\text { yang mencakup } & \text { proses } \\
\text { pengelolaan arsitektur data, } \\
\text { data induk, data referensi, } \\
\text { basis data, dan kualitas data } \\
\text { Gejalanya: } & \\
\text { - Keterbatasan } & \text { kemampuan } \\
\text { staf yang } & \text { memiliki } \\
\text { kompetensi } & \text { bidang } \\
\text { statistic } & \text { terutama } \\
\text { kompetensi } & \text { pengolahan } \\
\text { data \& } & \text { kompetensi } \\
\text { analisis data. } & \\
\text { Staf hanya } & \text { mampu } \\
\text { melakukan } & \text { pekerjaan } \\
\text { administrasi } & \end{array}$ & $\begin{array}{lr}\text { Dampak yang dirasakan } \\
\text { dengan adanya masalah } \\
\text { tersebut pembiayaan untuk } \\
\text { setiap } & \text { melaksanakan } \\
\text { kegiatan } & \text { proses } \\
\text { penyusunan data menjadi } \\
\text { lebih besar dan kurang } \\
\text { efisien. }\end{array}$ & $\begin{array}{lr}\text { Fakta dari masalah tersebut } \\
\text { akhirnya melakukan kerjasama } \\
\text { dengan pihak BPS atau perguruan } \\
\text { tinggi sebagai } r \text { terobosan } \\
\text { mengoptimalkan } & \text { kinerja, } \\
\text { walaupun } & \text { urusan } \\
\text { penyelenggaraan statistic telah } \\
\text { memiliki regulasi dan SOP yang } \\
\text { memadai. }\end{array}$ \\
\hline 7. & $\begin{array}{l}\text { Secara personal Kasubag } \\
\text { Penyusunan Program belum } \\
\text { banyak memahami yang } \\
\text { berkenaan dengan kebijakan } \\
\text { dan penerapan SPBE. } \\
\text { Kendala utamanya karena latar } \\
\text { belakang bukan rari } \\
\text { kompetensi } \\
\text { informasi. }\end{array}$ & $\begin{array}{l}\text { Dampak yang dirasakan } \\
\text { pekerjaan dilaksanakan } \\
\text { kurang optimal dan } \\
\text { mengganggu psikologis } \\
\text { saya secara personal, dan } \\
\text { ini dirasakan oleh personil } \\
\text { di sekretariat dinas. }\end{array}$ & $\begin{array}{l}\text { Berkenaan dengan hal tersebut } \\
\text { tugas saya sebagian besar banyak } \\
\text { dilaksanakan oleh pemegang } \\
\text { tupoksi lain. }\end{array}$ \\
\hline
\end{tabular}

2. Strategi Penguatan Kompetensi sumber daya manusia (SDM) bidang TIK Dinas Kominfo dan Statistik dalam rangka optimalisasi penerapan SPBE.

Dalam membentuk organisasi pembelajaran di lingkungan Dinas Komunikasi, Informatika dan Statistik, langkah-langkah strategis yang dilakukan adalah sebagai berikut :

a. Menyusun analisis kebutuhan strategi penguatan kompetensi SDM TIK, yaitu implementasi organisasi pembelajaran di lingkungan Diskominfotik adalah dengan mengkolaborasikan pembelajaran online (e-learning) dan pembelajaran 
konvensional

(laboratorium multimedia).

b. Membuat rancangan dan rencana pengembangan strategi penguatan kompetensi SDM TIK, yaitu mendefinisikan lingkup organisasi pembelajaran, membuat detail implementasi pembelajaran mencakup materi, kurikulum, waktu, tempat dan fasilitas pendukung.

c. Mentransformasikan strategi penguatan kompetensi SDM TIK, yaitu membuat strategi marketing untuk mempublikasikan inovasi proyek perubahan.

d. Membuat pra implementasi, yaitu menginventarisasi kesiapan implementasi.

e. Mengimplementasikan strategi penguatan kompetensi SDM TIK, yaitu mengimplementasikan program dan layanan strategi penguatan kompetensi SDM TIK.

\section{Hasil Capaian}

Strategi Penguatan Kompetensi SDM Teknologi Informasi \& Komunikasi (TIK) Dalam Mengoptimalkan Penerapan Sistem Pemerintahan Berbasis Elektronik (SPBE) dilaksanakan melalui beberapa tahapan.

Kegiatan jangka pendek untuk mendukung proyek perubahan Strategi Penguatan Kompetensi SDM Teknologi Informasi \& Komunikasi (TIK) Dalam Mengoptimalkan Penerapan Sistem Pemerintahan Berbasis Elektronik (SPBE), sebagaimana terlihat pada tabel berikut :

\begin{tabular}{|c|c|c|c|c|}
\hline No & Output Kunci & Tahapan & Kegiatan & Waktu \\
\hline \multirow[t]{4}{*}{$\mathbf{A}$} & \multirow[t]{4}{*}{$\begin{array}{l}\text { Tersusunnya hasil } \\
\text { analisis } \\
\text { kebutuhan } \\
\text { strategi } \\
\text { penguatan } \\
\text { kompetensi SDM } \\
\text { TIK }\end{array}$} & \multirow[t]{2}{*}{$\begin{array}{l}\text { 1. Membentuk tim } \\
\text { perancangan, pengembangan } \\
\text { dan implementasi strategi } \\
\text { penguatan kompetensi SDM } \\
\text { TIK }\end{array}$} & $\begin{array}{l}\text { 1. Mengidentifikasi } \\
\text { program, manager, } \\
\text { anggota tim dan } \\
\text { cakupan proyek tahap } \\
\text { awal dan batasan } \\
\text { waktu }\end{array}$ & $\begin{array}{c}\text { 26-30 } \\
\text { Agustus } 2019\end{array}$ \\
\hline & & & $\begin{array}{l}\text { 2. Mengklarifikasi } \\
\text { peran, tanggung } \\
\text { jawab, komitmen dan } \\
\text { membangun } \\
\text { kepaduan anggota } \\
\text { tim. }\end{array}$ & $\begin{array}{c}\text { 26-30 } \\
\text { Agustus } 2019\end{array}$ \\
\hline & & \multirow[t]{2}{*}{$\begin{array}{l}\text { 2. Mengidentifikasi arah } \\
\text { dan strategi organisasi dan } \\
\text { membangun dukungan } \\
\text { stakeholders }\end{array}$} & $\begin{array}{l}\text { 3. Pertemuan } \\
\text { dengan stakeholders } \\
\text { untuk mendapatkan } \\
\text { pemahaman tentang } \\
\text { bisnis mencakup } \\
\text { strategi, hambatan, } \\
\text { tantangan, wawasan, } \\
\text { peluang dan } \\
\text { pandangan terhadap } \\
\text { learning organization } \\
\text { (LO) serta kaitannya } \\
\text { dengan pencapaian } \\
\text { sasaran organisasi }\end{array}$ & $\begin{array}{c}2-6 \\
\text { September } \\
2019\end{array}$ \\
\hline & & & 4. Memberi arahan & 9 September \\
\hline
\end{tabular}


Vol. 2 No. 2 (2019)

\begin{tabular}{|c|c|c|c|c|}
\hline & & & $\begin{array}{l}\text { project manager dan } \\
\text { koordinator untuk } \\
\text { mengidentifikasi dan } \\
\text { membangun } \\
\text { kolaborasi serta } \\
\text { mengasess } \\
\text { infrastruktur, peran, } \\
\text { proses, teknologi, } \\
\text { program dan layanan. }\end{array}$ & 2019 \\
\hline & & & $\begin{array}{l}\text { 5. Membangun } \\
\text { Aplikasi e-Learning }\end{array}$ & $\begin{array}{c}2-9 \\
\text { September } \\
2019\end{array}$ \\
\hline & & $\begin{array}{l}\text { 3. Pemetaan Kompetensi } \\
\text { SDM }\end{array}$ & $\begin{array}{l}\text { 6. Mengidentifikasi } \\
\text { kondisi eksisting } \\
\text { kompetensi SDM } \\
\text { TIK }\end{array}$ & $\begin{array}{c}10-11 \\
\text { September } \\
2019\end{array}$ \\
\hline & & \multirow[t]{2}{*}{$\begin{array}{l}\text { 4. Melaksanakan rapat } \\
\text { untuk mendefinisikan model } \\
\text { dan strategi peningkatan } \\
\text { kompetensi SDM TIK }\end{array}$} & $\begin{array}{l}\text { 7. Menganalisa } \\
\text { kondisi eksisting } \\
\text { organisasi terkait } \\
\text { gambaran kebutuhan }\end{array}$ & $\begin{array}{c}11-13 \\
\text { September } \\
2019\end{array}$ \\
\hline & & & $\begin{array}{l}\text { 8. Mendefinisikan } \\
\text { sasaran, model, dan } \\
\text { standarisasi }\end{array}$ & $\begin{array}{c}\text { 11-13 } \\
\text { September } \\
2019\end{array}$ \\
\hline \multirow[t]{4}{*}{$\mathbf{B}$} & \multirow{4}{*}{$\begin{array}{l}\text { Terbentuknya } \\
\text { rancangan dan } \\
\text { rencana } \\
\text { pengembangan } \\
\text { strategi } \\
\text { penguatan } \\
\text { kompetensi SDM } \\
\text { TIK }\end{array}$} & \multirow[t]{2}{*}{$\begin{array}{l}\text { 5. Melakukan studi } \\
\text { banding Bench Marking cara } \\
\text { menselaraskan business } \\
\text { needs, strategy dan goals }\end{array}$} & $\begin{array}{l}\text { 9. Studi banding ke } \\
\text { organisasi yang } \\
\text { relevan untuk } \\
\text { mendapatkan } \\
\text { gambaran detail }\end{array}$ & $\begin{array}{c}18 \text { September } \\
2019\end{array}$ \\
\hline & & & $\begin{array}{l}\text { 10. Menganalisis } \\
\text { hasil dan membuat } \\
\text { laporan }\end{array}$ & $\begin{array}{c}19-20 \\
\text { September } \\
2019\end{array}$ \\
\hline & & $\begin{array}{l}\text { 6. Membangun rencana } \\
\text { awal strategi penguatan } \\
\text { kompetensi SDM TIK }\end{array}$ & $\begin{array}{l}\text { 11. Mendefinisikan } \\
\text { lingkup proyek dan } \\
\text { waktu penyelesaian } \\
\text { proyek }\end{array}$ & $\begin{array}{c}\text { 16-17 } \\
\text { September } \\
2019\end{array}$ \\
\hline & & $\begin{array}{l}\text { 7. Membuat program dan } \\
\text { kurikulum pengembangan } \\
\text { kompetensi pegawai }\end{array}$ & $\begin{array}{l}12 . \text { Membuat } \\
\text { rancangan detail } \\
\text { kurikulum, peta } \\
\text { kurikulum dan } \\
\text { rencana implementasi }\end{array}$ & $\begin{array}{c}26-27 \\
\text { September } \\
2019\end{array}$ \\
\hline \multirow[t]{2}{*}{$\mathbf{C}$} & $\begin{array}{l}\text { Transformasi } \\
\text { strategi } \\
\text { penguatan } \\
\text { kompetensi SDM } \\
\text { TIK }\end{array}$ & $\begin{array}{l}\text { 8. Membuat rencana tahapan } \\
\text { implementasi dan change } \\
\text { management strategi } \\
\text { penguatan kompetensi SDM } \\
\text { TIK }\end{array}$ & $\begin{array}{l}\text { 13. Membuat } \\
\text { implementation dan } \\
\text { launch plan strategi } \\
\text { penguatan } \\
\text { kompetensi SDM } \\
\text { TIK }\end{array}$ & $\begin{array}{c}30 \text { September } \\
2019\end{array}$ \\
\hline & & & $\begin{array}{l}\text { 14. Membuat } \\
\text { marketing \& } \\
\text { communication plan } \\
\text { untuk program dan } \\
\text { layanan }\end{array}$ & $\begin{array}{c}1 \text { Oktober } \\
2019\end{array}$ \\
\hline D & Pra Implementasi & 9. Menginventarisasi & 15. Inventarisasi & 2-4 Oktober \\
\hline
\end{tabular}


Vol. 2 No. 2 (2019)

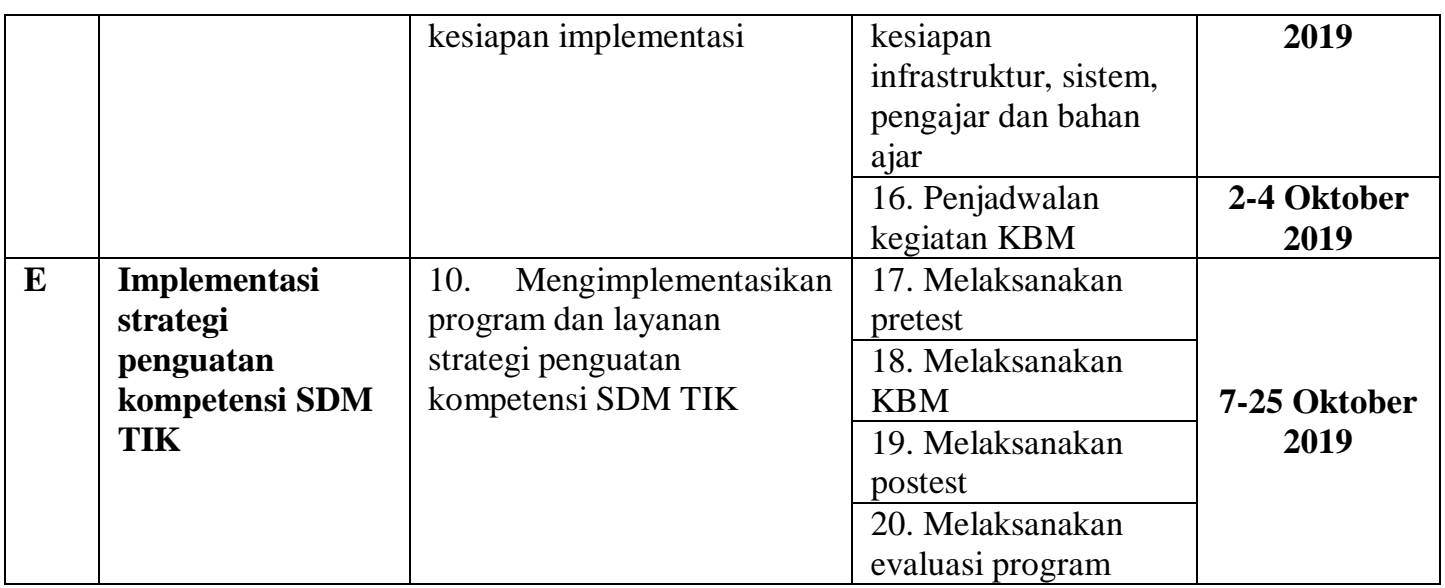

\section{Kesimpulan}

1. SDM TIK merupakan bagian terpenting dalam Mengoptimalkan Penerapan Sistem Pemerintahan Berbasis Elektronik (SPBE), sehingga diperlukan suatu strategi yang tepat untuk dapat menguatkan kompetensi SDM TIK.

2. Dari hasil evaluasi terhadap nilai pretest dan postest terdapat peningkatan yang signifikan terhadap kompetensi SDM.

3. Output yang dihasilkan :

- Terbangunnya aplikasi $e$ learning di Dinas Komunikasi, Informatika dan Statistik.

- Terbangunnya laboratorium multimedia di Dinas Komunikasi, Informatika dan Statistik.

Outcome yang diperoleh :

- Meningkatnya attitude, knowledge dan skill pegawai Dinas Komunikasi, Informatika dan Statistik

- Terbangunnya knowledge sharing dari masing-masing pegawai di Dinas Komunikasi, Informatika dan Statistik

\section{Rekomendasi}

1. Strategi ini dapat diimplementasikan tidak hanya pada bidang TIK, akan tetapi dapat diimplemetasikan pada bidang yang lain.

2. Strategi ini dapat lebih berkembang jika diimplementasikan pada BKPSDM.

3. Strategi Penguatan Kompetensi SDM Teknologi Informasi \& Komunikasi (TIK) dalam Mengoptimalkan Penerapan Sistem Pemerintahan Berbasis Elektronik (SPBE) menjadi rintisan pembentukan corporate university di tingkat Pemerintah Daerah.

\section{DAFTAR PUSTAKA}

\section{Buku :}

Darmawan, D. (2014). Pengembangan ELearning: Teori dan Desain. Bandung: PT Remaja Rosdakarya

Henry Simamora (2001), Manajemen Sumber Daya Manusia, Edisi kedua, STIE YPKN, Yogjakarta, Manajemen Peningkatan Kompetensi Aparatur : Studi tentang Implementasi Kebijakan Reformasi 
Vol. 2 No. 2 (2019)

Sumber Daya Manusia pada Badan Pendidikan dan Pelatihan di Indonesia, Ratu Megalia, Sosio Humanika, Vol 4 No 2 tahun 2011

Muhamad Ali Prosiding Sentia, (2009) Peningkatan Kualitas Pendidikan dan Pembelajaran Melalui Teknologi Informasi dan Komunikasi di Universitas Negeri Yogjakarta, Politeknik Negeri Malang

Rahardjo, B, (2000). Implikasi Teknologi Informasi dan Internet Terhadap Pendidikan Bisnis, dan Pemerintahan, http//gora.edublogs.org/2007/TIK.h tml

Rahmawati,Model Pembelajaran berbasis e-Learning dalam rangka meningkatkan Kompetensi dan Profesionalisme Bendahara Pengeluaran di Lingkungan Pemerintad daerah,
Sugiyono, (2013) Metode Penelitian Kombinasi (Mixed Methods), Alfabeta Bandung,

Surjono, H.D (2013) Membangun course e-learning berbasis moodle. Yogjakarta: UNJ Press

\section{Dokumen :}

Teknologi Informasi \& Komunikasi (TIK) di Dinas Kominfo dan Statistik Kabupaten Bandung Barat.

Perpres 95 tahun 2018 tentang Sistem Pemerintahan Berbasis Elektronik

Peraturan Menteri Komunikasi dan Informatika Republik Indonesia Nomor 24 Tahun 2015 tentang Pemberlakuan Standar Kompetensi Kerja Nasional Indonesia Bidang Komunikasi dan Informatika

Perpres 95 tahun 2018 tentang Sistem Pemerintahan Berbasis Elektronik 